DOI: $10.31249 / \mathrm{rsm} / 2019.03 .12$

\title{
M.A. Ядова
}

\section{МОАЕРНИЗАЦИОННЫЙ ПОТЕНЦИАА И МОАЕРНИЗАЦИОННЫЙ КАПИТАА: ГРАНИ ВЗАИМОАЕЙСТВИЯ}

Аннотация. В работе анализируются индивидуальные и сочиальные сильные / слабые ресурсы (стартовый капитал социального происхождения, уровень образования, материальной обеспеченности, проживание в крупном городе / глубинке, способности к адаптации, число и характер формальных / неформальных связей, уровень притязаний и пр.), влияющие на поведение и модернизационный потенциал человека. Вводится понятие модернизационного капитала личности, под которым предлагается понимать совокупность социальных ресурсов и индивидуальных особенностей личности, формирующих предрасположенность индивида к тому, что принято называть современным типом поведения, и способствующчих успешному освоению соответствующих иенностей, поведенческих паттернов. Рассматриваются факторы, определяющче преобразование модернизациионного потенцииала в модернизационный капитал. Такая трансформация сложна без создания благоприятных для социильного обновления условий. Только в реально модернизирующемся обществе капитал станет «работать», накапливаясь и возвращая его обладателю вложенные «инвестиичи». Показано, что модернизационный капитал личности является одним из ключевых условий сочиально-экономического развития общества. Утверждается, что принадлежность к сильноресурсной группе населения повытает шансы на адаптацию к новым социальным условиям, а также на индивидуальную «модернизачию». Кроме того, результаты проведенного автором эмпирического исследования показывают, что при усвоении индивидом новых и традиционных иенностей значительную роль играет его социальное окружение. В целом настоящее исследование продемонстрировало, что постсоветская молодежь потенииально готова к социильной модернизации. В будущеем при благоприятных внешних условиях молодое поколение может стать движущей силой, способной к изменению и обновлению российского общества.

Ключевые слова: модернизация российского общества; социильные ресурсы; модернизационный потенцииал; модернизационный капитал; постсоветская молодежь.

Ядова Майя Андреевна - кандидат социологических наук, заведующая отделом социологии и социльной психологии 


\section{РАЗМЫШЛЕНИЯ, СООБЩЕНИЯ, КОММЕНТАРИИ}

Института научной информации по общественным наукам РАН

(ИНИОН РАН). Е-mail: m.yadova@mail.ru

\section{M.A. Yadova. Modernization Potential and Modernization Capital: Facets of Interaction}

Absract. Personal and social strong / weak resources (start-up capital of social origin, level of education and material security, living in a large city / the backwoods, adaptive abilities, number and character of formal / informal contacts, personal networks, level of aspiration, etc.) that have an impact on human behaviour and modernization potential are being analyzed in this paper. There is introduced a notion of personality's modernization capital proposed to be understood as an aggregate of social resources and individual personality peculiarities that form individual predisposition to what is commonly called the modern type of behaviour and facilitate successful mastering of appropriate values, behavioural patterns. There are considered issues that facilitate transformation of modernization potential into modernization capital. It is shown that personality's modernization capital is one of the key conditions of the social and economic development of society. It is argued that belonging to the high-resource population group ("modern》 social environment) increases chances of individual «modernization» and adaptation to new social conditions. In general, our findings showed that the post-Soviet young people possess certain modernization potential; they are ready for social modernization. The author suggests that in the future, under favorable external environment, youth can become a driving force for changes and modernization of Russian society.

Keywords: modernization of Russian society; social resources; modernization potential; modernization capital; post-Soviet youth.

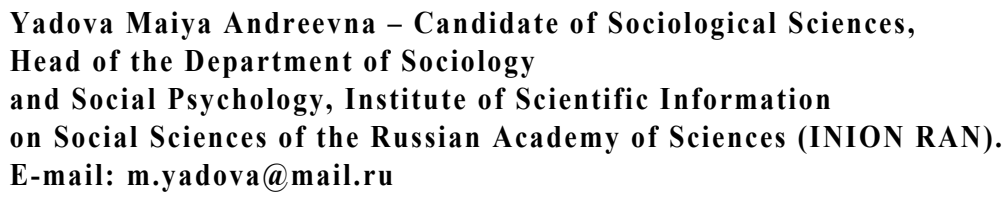

Тему модернизации можно отнести к вечным для нашей страны: каждый новый кризисный момент инициирует очередную волну дискуссий о необходимости модернизации российского общества. Некоторые исследователи считают, что для России характерно - зачастую в имплицитной форме - одновременное протекание модернизационных и демодернизационных процессов [Королев 2009 a; Королев 2009 b]. Как бы то ни было, важность и целесообразность завершения модернизационных процессов в российском социуме, кажется, признают все. Член-корреспондент РАН Н.И. Лапин называет сегодняшнюю Россию «полуоткрытым обществом» [Лапин 2018, с. 11], которое находится в пограничном состоянии и крайне медленно модернизируется. Это, считает он, способно породить если не социальный взрыв, то серьезные 
обострения накопившихся социальных противоречий. Несмотря на то что Россия, по его мнению, вступила в подготовительную фазу вторичной модернизации, уровень модернизированности большинства региональных сообществ невысок и весьма полярен (от клановой архаики до общества знаний).

В подобных условиях именно человеческие ресурсы можно рассматривать в качестве реальной опоры для модернизационных процессов в нашей стране. Представляется важным понять, какие группы населения потенциально наиболее восприимчивы к ценностям модерна ${ }^{1}$ и могли бы стать основными акторами социальных изменений. Как показывают результаты многочисленных массовых опросов, готовность к саморазвитию, открытость переменам и адаптивную гибкость обычно демонстрируют обладатели сильного «личностного» капитала.

Именно личностный капитал отдельного человека - его индивидуальные особенности и ресурсы - считаются ключевыми факторами, определяющими поведение человека [Тихонова 2004; Ядов 2001; Portes 1998]. Кратко остановимся на наиболее «сильноресурсных» детерминантах, характерных для России [подробнее см.: Ядов 2001, с. 314-317].

1. Прежде всего, это «стартовый капитал» социального происхождения и первичной социализации, а именно - воспитание в достаточно благополучной, статусной, материально обеспеченной родительской семье.

2. Хорошее образование и высокая квалификация. Образование и профессиональная подготовка нередко определяют положение человека на всех этапах его жизненного пути. По словам польского социолога П. Штомпки, хорошее образование способствует преодолению «культурной травмы» [Штомпка 2001, с. 14]: хорошо образованные люди легче адаптируются к изменившимся социальным условиям.

3. Материальная обеспеченность, несомненно, является одним из важнейших социальных ресурсов. В настоящее время в российском обществе насчитывают около $30 \%$ бедных, причем наблюдается тенденция к консервации бедности, т.е. закрепление доли людей, находящихся в экономически депривированном состоянии более пяти лет. Также получает распространение процесс «наследования» бедности [Бедность и неравенства 2013].

4. Молодой возраст и хорошее здоровье как естественные ресурсы. Впрочем, для ряда групп молодежи - сельской, безработной, выходцев из малоимущих семей - данные преимущества не кажутся очевидными.

1. В настоящей работе под современными будем понимать характеристики «современной личности», сформулированные американским соииологом А. Инкелесом: открытость новому опыту, сочиальная ответственность и активность, законопослушность, толерантность, самостоятельность, интернальность и пр. [Inkeles 1974]. 
5. Проживание в мегаполисе или крупном городе в отличие от «глубинки» и сельской местности значительно повышает шансы успешно адаптироваться к происходящим социальным изменениям.

6. Наличие обширных межсличностных связей и «полезных знакомств».

7. Британская исследовательница Т. Басит, анализируя образовательные и профессиональные устремления молодых британцев, предлагает дополнить теорию социального и культурного капитала идеей так называемого acnupaционного капитала (aspirational capital), важными составляющими которого являются высокие карьерные устремления, что повышает шансы на жизненный успех [Basit 2012]. В небогатых семьях аспирационный капитал нередко заменяет недостающие ресурсы культурного и социального капитала.

8. В числе личностных сильных ресурсов одно из основных мест занимает высокий уровень самооценки, поскольку без высокой (но не завышенной) самооценки невозможны саморазвитие и личностный рост.

9. Внутренний локус контроля (интернальность) в противовес внешнему, т.е. желание человека видеть источник управления своей жизнью в самом себе, а не во внешних обстоятельствах.

10. Как уже говорилось выше, еще одним значительным индивидуальным ресурсом является способность к адаптации. Россияне, особенно молодые и среднего возраста, все чаще готовы предпринимать действенные шаги по улучшению своего положения (сменить профессию, пройти переобучение, «уйти» в теневой сектор экономики) [Плюснин, Позаненко 2015].

Таким образом, можно сделать вывод, что для сильноресурсных социальных групп адаптация к новым условиям относительно облегчена, что повышает их шансы на успешную индивидуальную «модернизацию» наравне с общественной. Это дает возможность говорить не только о модернизационном потенциале, но и модернизационном капитале человека. Под первым будем понимать наличие отдельных ресурсов, повышающих адаптивные возможности человека в условиях модернизации. Тогда как термином «модернизационный капитал» предлагаем обозначить совокупность социальных ресурсов и индивидуальных особенностей личности, формирующих предрасположенность индивида к тому, что принято называть современным типом поведения, и способствующих успешному освоению соответствующих ценностей, поведенческих паттернов. Для преобразования потенциала в капитал необходима мотивация человека, внутренняя готовность к социальной модернизации и факторам ее проявления, наличие соответствующих персональных - «модернизационных» - ценностных и поведенческих установок. Такая трансформация чрезвычайно сложна без создания благоприятных для социального обновления условий. Только в реально модернизирующемся обществе подобный капитал станет «работать», накапливаясь и возвращая его обладателю вложенные «инвестиции». 
Если задаться целью сконструировать социальный портрет идеального обладателя модернизационного капитала, получится следующее: представитель(ница) молодого поколения, с хорошим образованием, выросший или живущий в мегаполисе, обладающий достаточно «сильным» набором социальных ресурсов, демонстрирующий ярко выраженные достижительные установки, открытый новациям и изменениям, по личностным качествам соответствующий «modern personality».

Кстати, по данным проведенного автором статьи эмпирического исследования постсоветской молодежи, гипотеза о связи между модернизмом человека и его «ресурсоемкостью» подтвердилась: доля «модернистов» в сильноресурсной подвыборке выше, чем в слаборесурсной (ср.: 23\% vs 5\%) [см., например: Ядова 2012]. Также было обнаружено, что при усвоении индивидом новых и традиционных ценностей немалую роль играет социальное окружение. Для «модернистов» в роли «значимых других» часто выступают современные люди - те, кто социально активен, независим и пр. Уважение же «традиционалистов», как правило, вызывали авторитарные личности [см.: Ядова 2011, с. 272].

Вышеизложенное дает надежду предположить, что постсоветская молодежь потенциально готова к социальной модернизации. В будущем при благоприятных внешних условиях представители этого поколения могут стать той силой, которая действительно способна к обновлению российского общества.

\section{Библиография}

Бедность и неравенства в современной России: 10 лет спустя: Аналитический доклад / Под ред. М.К. Горшкова, Н.Е. Тихоновой. М.: Институт социологии РАН, 2013. 168 с.

Королев С.А. Модернизация и демодернизация в российской истории. Ч. 1 // Философия и культура. 2009 а. № 1 (13). С. $72-80$.

Королев С.А. Модернизация и демодернизация в российской истории. Ч. 2 // Философия и культура. 2009 b. № 2 (14). С. 37-45.

Лапин Н.И. Антропосоциокультурный эволюционизм - метатеоретический принцип изучения сообществ людей // Социологические исследования. 2018. № 3. С. 3-14. DOI: $10.7868 / \mathrm{S} 0132162518030017$

Плюснин Ю.М., Позаненко А.А., Жидкевич Н.Н. Отходничество как новый фактор общественной жизни // Мир России. 2015. № 1. С. 35-71.

Тихонова Н.Е. Социальный капитал как фактор неравенства // Общественные науки и современность. 2004. № 4. С. 24-35.

Штомпка П. Социальные изменения как травма // Социологические исследования. 2001. № 1. C. 6-16.

Ядова М.А. «Модернисты» и «традиционалисты» постсоветского поколения: Особенности индивидуальных биографий // Социологический ежегодник. 2011. С. 264-280.

Ядова М.А. Современное и традиционное в ценностях постсоветской молодежи // Социологические исследования. 2012. № 1. С. 114-125. 


\section{РАЗМЫШЛЕНИЯ, СООБЩЕНИЯ, КОММЕНТАРИИ}

Ядов В.А. Социальный ресурс индивидов и групп как их капитал: Возможность применения универсальной методологии исследования реального расслоения в российском обществе // Кто и куда стремится вести Россию? / Под ред. Т.И. Заславской. М.: МВШСЭН, 2001. С. 310 319.

Basit T.N. «My parents have stressed that since I was a kid»: Young minority ethnic British citizens and the phenomenon of aspirational capital // Education citizenship and social justice. 2012. Vol. 7. No 2. P. 129-143.

Inkeles A., Smith D.H. Becoming modern. Cambridge (MA): Harvard univ. press, 1974. 436 p.

Portes A. Social capital: Its origins and applications in modern sociology // Annual review of sociology. 1998. Vol. 24. P. 1-24.

\section{References}

Basit T.N. «My parents have stressed that since I was a kid»: Young minority ethnic British citizens and the phenomenon of aspirational capital. Education citizenship and social justice. 2012. Vol. 7. No 2. P. 129-143.

Bednost' i neravenstva v sovremennoj Rossii: 10 let spustya: Analiticheskij doklad. Pod red. M.K. Gorshkova, N.E. Tikhonovoj. Moscow: Institut sociologii RAN, 2013. 168 p.

Inkeles A., Smith D.H. Becoming modern. Cambridge (MA): Harvard univ. press, 1974. 436 p.

Korolev S.A. Modernizaciya i demodernizaciya v rossijskoj istorii. Ch. 1. Filosofiya i kul'tura. 2009 a. No 1 (13). P. 72-80.

Korolev S.A. Modernizaciya i demodernizaciya v rossijskoj istorii. Ch. 2. Filosofiya i kul'tura. 2009 b. No 2 (14). P. 37-45.

Lapin N.I. Antroposociokul'turnyj evolyucionizm - metateoreticheskij princip izucheniya soobshchestv lyudej. Sociologicheskie issledovaniya. 2018. No 3. P. 3-14. DOI: 10.7868/S01321625 18030017

Plyusnin Yu.M., Pozanenko A.A., Zhidkevich N.N. Othodnichestvo kak novyj faktor obshchestvennoj zhizni. Mir Rossii. 2015. No 1. P. 35-71.

Portes A. Social capital: Its origins and applications in modern sociology. Annual review of sociology. 1998. Vol. 24. P. 1-24.

Shtompka P. Social'nye izmeneniya kak travma. Sociologicheskie issledovaniya. 2001. No 1. P. 6-16.

Tikhonova N.E. Social'nyj kapital kak faktor neravenstva. Obshchestvennye nauki i sovremennost'. 2004. No 4. P. 24-35.

Yadova M.A. «Modernisty» i «tradicionalisty» postsovetskogo pokoleniya: Osobennosti individual'nyh biografij. Sociologicheskij ezhegodnik. 2011. P. 264-280.

Yadova M.A. Sovremennoe i tradicionnoe v cennostyah postsovetskoj molodezhi. Sociologicheskie issledovaniya. 2012. No 1. P. 114-125.

Yadov V.A. Social'nyj resurs individov i grupp kak ih kapital: Vozmozhnost' primeneniya universal'noj metodologii issledovaniya real'nogo rassloeniya v rossijskom obshchestve. Kto i kuda stremitsya vesti Rossiyu? Pod red. T.I. Zaslavskoj. Moscow: MVSHSEN, 2001. P. 310-319. 